\title{
MUNICIPAL IOT IMPLEMENTATION STRATEGY FOR BRASÍLIA, BRAZIL: SMART CITY GUIDELINES AT THE LOCAL LEVEL
}

\author{
FELIPE MUÑOZ LA RIVERA ${ }^{1,2,3}$, BRUNO ÁVILA EÇA DE MATOS ${ }^{4} \&$ VICTOR LOZANO-IGUALT $^{5}$ \\ ${ }^{1}$ School of Civil Engineering, Pontificia Universidad Católica de Valparaíso, Chile \\ ${ }^{2}$ School of Civil Engineering, Universitat Politècnica de Catalunya, Spain \\ ${ }^{3}$ International Centre for Numerical Methods in Engineering (CIMNE), Spain \\ ${ }^{4}$ Department of Built Environment, Eindhoven University of Technology (TUE), Netherlands \\ ${ }^{5}$ Inmobiliaria e Inversiones Malpo Limitada, Chile
}

\begin{abstract}
While cities face multiple challenges, population growth must be combined with resource efficiency and sustainability. In this context, many municipalities intend to become smart cities, where good urban management practices are combined with various technologies to generate highly connected and monitored cities, aiming to improve the quality of life of their inhabitants. In Brasília, the capital of Brazil, while several individual initiatives have emerged in this direction, a comprehensive plan for the implementation of a smart city has not yet been consolidated. This research proposes an action plan for making Brasília a smart city, with a focus on enabling Internet of Things (IoT) at the municipal level. The strategy is based on a local diagnosis of socio-economic aspects, technological landscape and regulatory constraints, and brings together a series of recommendations and references of projects that could be implemented in the city to make urban public services more efficient.
\end{abstract}

Keywords: Internet of Things (IoT), smart cities, public policy, urban management, urban infrastructure, Brazil, Sustainable Development Goals (SDGs).

\section{INTRODUCTION}

Global negotiations reached targets to guide the efforts of nations to build a more just and responsible world, such as the Sustainable Development Goals (SDG). In order to achieve them, the strategic management plans that nations generate in these matters are relevant. Along with them, new technologies play a fundamental role in making it possible for intentions to come to life, optimizing the scarce resources available, especially in less developed countries. Within these plans with good intentions, cities play a fundamental role [1]. Smart cities today represent an urban management model, where the strategic management of municipalities, together with a wide deployment of technology, seek to improve the well-being of the inhabitants in matters of transportation, environment, quality of infrastructure and urban services in general [2]. In this context, the Internet of Things (IoT) is a key technology, since it provides an opportunity for cities to have more efficient public services while still encompassing the matter of social disparities, improving the quality of life by making cities capable of implementing these technological advances while also minding social concerns [3].

Various cities in the world are turning into the smart city paradigm. In addition to urban renovations and strategic management plans, the implementation of $5 \mathrm{G}$ and IoT are elements that stand out in most successful implementation cases [4]. The most digitized cities in the world, in Asia, Europe or North America, today have extensive IoT networks, and seek to expand these systems to improve and increase the amount of interconnected services. For example, in the case of New York, the guidelines for smart cities propose and regulate the use of the IoT in a coordinated manner between public and private entities, promoting the privacy, transparency and security of the city's infrastructures and data [5]. On the other 
hand, Barcelona has implemented a network of sensors throughout the city, which in real time thanks to the IoT allow monitoring a series of environmental factors and the quality of interconnected services. In Latin America, although there are smart city plans, mainly for capital cities, implementation is slower. Smart city plans seek to promote these trends, however, specific guidelines are not yet completed, and mainly specific initiatives are implemented, in many cases, not integrated. In the case of Brazil, the main initiatives are in Rio de Janeiro, where smart lighting plans and public Wi-Fi networks stand out as pioneers; and in Brasília, where technological development initiatives for the efficiency and monitoring of sanitation, energy and communications services have begun to be promoted in the last decade [6].

In this context, this paper identifies the contribution of IoT and smart city planning for Brasília, in response to the needs of the city and the particular initiatives that are under development. Thus, strategic actions are proposed for the successful deployment of these new technologies on a massive scale in the city, with a view to its transformation into a smart city. The research methodology is divided into three stages: (1) Smart city elements and models; (2) Diagnosis; and (3) Action plan. In the first stage, the elements of technological infrastructure, strategies, methods and case studies for the implementation of smart cities are identified. In the second stage, a diagnosis of the city of Brasília is developed, focused on understanding its socio-economic, technological and regulatory context. Finally, based on the previous stages, an action plan to implement IoT for smart city applications in Brasília is developed. Fig. 1 shows a diagram of the research methodology, with the stages, activities, research tools and deliverables.

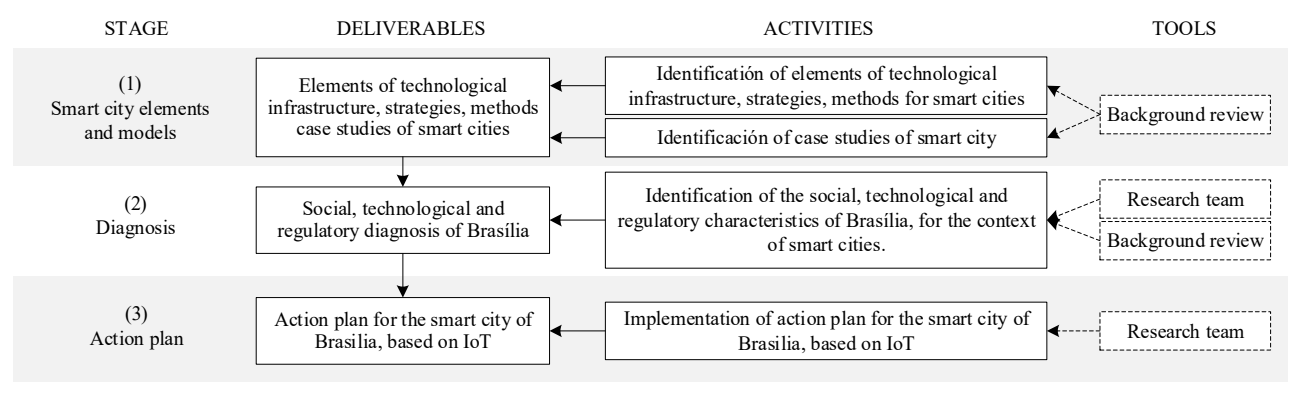

Figure 1: Research methodology.

\section{BACKGROUND}

\subsection{IoT urban infrastructure elements}

The urban infrastructure of information and communication technologies (ICT) is based on providing conditions for data traffic between data consumers in the city and data centers located in other cities, countries or continents [7]. With the popularization of the Internet, a global network of data traffic was consolidated. ICT infrastructures in urban spaces are made up of three main components: access network, transport network and data storage [2]. The access network, also called the last mile network, corresponds to the most peripheral ICT infrastructure, where information is collected and distributed to each of the homes, offices or users in general. The transport network, also called the backbone, is the central component of the telecommunications networks that connects the different access networks and other 
parts of the IT system. The third component is data storage, which must keep the data over time for use when required by a user from a computer or other type of device.

Understanding an IoT architecture for urban utility devices can be simplified for public policy purposes in a system with three layers: device layer, network layer, and service layer [8]. Fig. 2 shows this simplified architecture on a municipal scale, identifying its main elements and relating the layers to the broader structures of the telecommunications system. It can be noted that a typical IoT municipal infrastructure implementation includes the deployment of multiple technologies and requires a broad diversity of expertise [9].

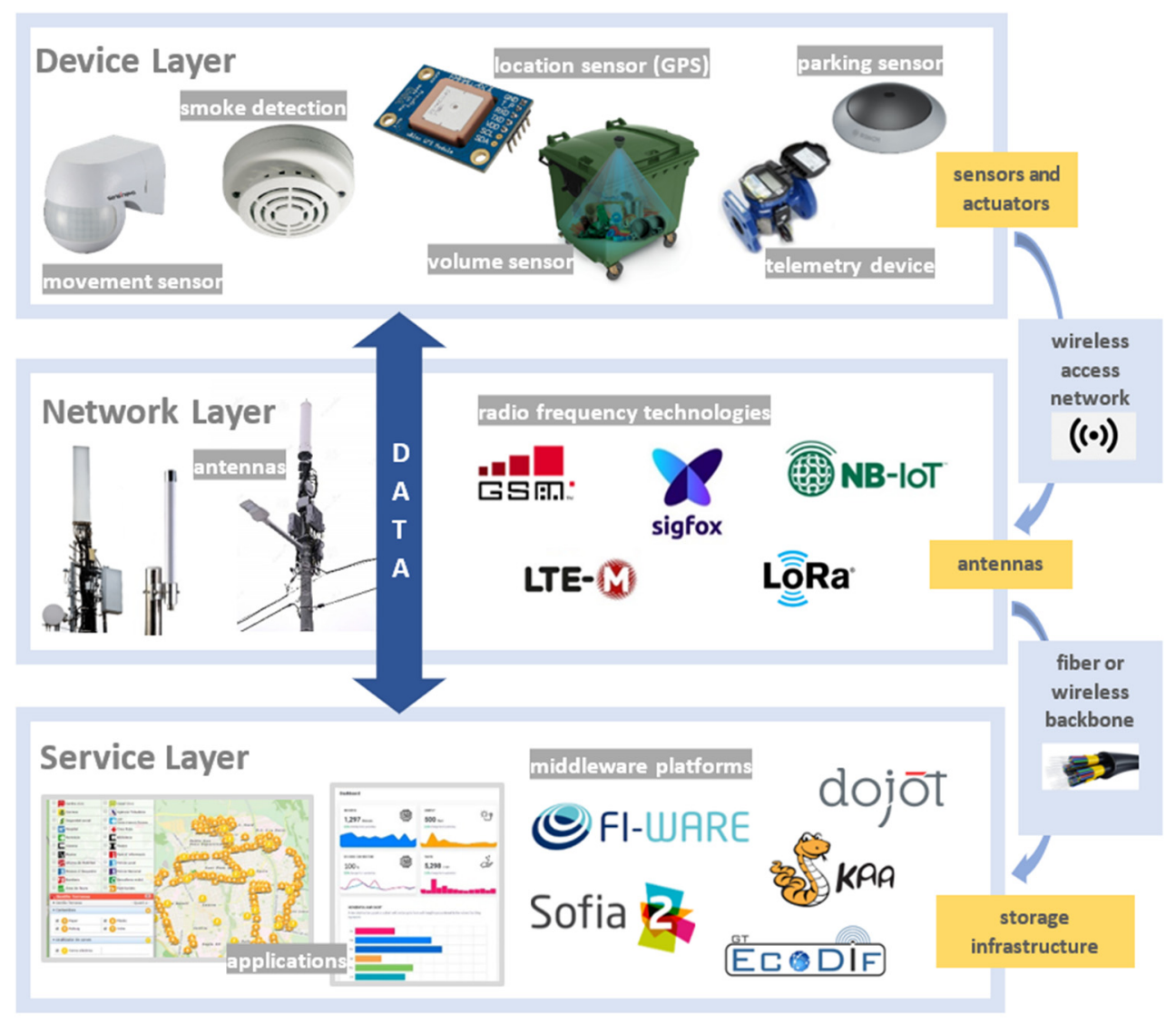

Figure 2: IoT urban infrastructure diagram for public services.

\subsection{Case studies of IoT implementation for smart cities}

The planning, development and consolidation of a smart city strategy is a complex process that requires the incorporation of different elements that provide answers to multiple variables to be studied in a specific environment [10]. It is evident that the particularities of each territory must be resolved according to its needs, legal aspects, cultural elements and idiosyncrasies, but international references can also be very useful as a guide. In this context, Table 1 shows six case studies of initiatives that could be interesting to guide potential 
guidelines to be followed in the context of the city of Brasília. These have been selected based on the characteristics of the IoT to be implemented, focused on implementation aspects, regulations, forms of contracting, among others.

Table 1: IoT implementation case studies for smart cities.

\begin{tabular}{|c|c|}
\hline City & Description of initiative \\
\hline $\begin{array}{l}\text { New York } \\
\text { (U.S.A.) }\end{array}$ & $\begin{array}{l}\text { Common framework for government entities, seeking to maximize } \\
\text { transparency and openness regarding design, installation and operation, } \\
\text { provide clarity on minimum requirements and expectations, and promote } \\
\text { public dialogue on how government, industry Private and academic } \\
\text { partners can maximize the public benefit of IoT solutions. They address } \\
\text { aspects of Privacy and Transparency; Data management; Infrastructure; } \\
\text { Security; and Operations and Sustainability [11]. }\end{array}$ \\
\hline $\begin{array}{l}\text { Seoul } \\
\text { (South } \\
\text { Korea) }\end{array}$ & $\begin{array}{l}\text { The city has undergone a series of transformations and policies to provide } \\
\text { the city with state-of-the-art technology. Smart Seoul Network (S-Net) will } \\
\text { give all citizens access to the Internet through the deployment of a new } \\
\text { smart city infrastructure, based on the establishment of a municipal } \\
\text { broadband network, the deployment of free Wi-Fi networks and further } \\
\text { integration of IoT infrastructure based on LoRa devices [12]. }\end{array}$ \\
\hline $\begin{array}{l}\text { Barcelona } \\
\text { (Spain) }\end{array}$ & $\begin{array}{l}\text { The open source Sentilo platform in Barcelona consolidates the } \\
\text { applications that are developed to use and take advantage of the } \\
\text { information "generated by the city" and the layer of sensors deployed by it, } \\
\text { to collect and disseminate this information. Sentilo makes it possible to fit } \\
\text { into the smart city architecture of any city that seeks openness and simple } \\
\text { interoperability. It is designed as a cross platform, in order to share } \\
\text { information with heterogeneous systems and integrate similar applications } \\
\text { [13]. }\end{array}$ \\
\hline $\begin{array}{l}\text { Jaipur } \\
\text { (India) }\end{array}$ & $\begin{array}{l}\text { The smart city plan is based on important high-tech and scientific } \\
\text { strategies. The first phase is already in the process of turning Jaipur into a } \\
\text { smart city with the use of ICT and Communication based interventions. On } \\
\text { the other hand, the second phase seeks to implement initiatives for the } \\
\text { digitization of citizen services and E-governance [14]. }\end{array}$ \\
\hline $\begin{array}{l}\text { Las Vegas } \\
\text { (U.S.A.) }\end{array}$ & $\begin{array}{l}\text { The plan seeks to improve the interoperability of transportation, energy, } \\
\text { public works, facilities and public safety, law enforcement through open } \\
\text { source data sharing, real-time data analysis, and decision-making support. } \\
\text { It pursues to keep people safe and connected, and provide them with the } \\
\text { information they seek when they need it, based on a public-private } \\
\text { partnership [15]. }\end{array}$ \\
\hline $\begin{array}{l}\text { Rio de } \\
\text { Janeiro } \\
\text { (Brazil) }\end{array}$ & $\begin{array}{l}\text { The plan integrates projects that support the strategic planning of the local } \\
\text { government, strengthening the relationship of citizens with the city and the } \\
\text { government. It considers the local monitoring service of the city's } \\
\text { Operations Center, and a digital inclusion program, an important indicator } \\
\text { that tracks the population's access to new technologies, especially in } \\
\text { disadvantaged communities in the city [16]. }\end{array}$ \\
\hline
\end{tabular}




\subsection{Smart city implementation models}

Like any public service, the implementation of a municipal IoT infrastructure for smart urban management, especially of connected devices, antennas and the backbone network, requires a solid and transparent structured model so that the local government can meet the objectives of their public policies [17]. Three implementation models were identified: (1) Construction and ownership; (2) Subscription; and (3) Public-Private Partnership (PPP). In the first, a government agency develops specific requirements for an IoT network, prepares a competitive bidding process, and establishes a contract with a company to implement the network with predetermined requirements. In the second type, private companies define the requirements according to market demands, build and operate the connectivity network. The government periodically pays network utilization fees to companies established to implement their IoT projects. On the other hand, in the PPP model, a tender is opened for the implementation and maintenance of the network, which is built and administered by the chosen company. The contract provides for its use by public devices at no cost or at a previously determined cost. At the end of the term, the implanted infrastructure remains owned by the government [18].

According to the guidelines of the National Bank for Economic and Social Development (BNDES) of Brazil, Fig. 3 shows the eight steps that must be considered for structuring a device connectivity strategy for an integrated smart city solution, in this case, for the city of Brasília. The process starts with a political decision and the creation of a multidisciplinary implementation team. As the project is minimally structured, citizens are able to provide input and assist in determining the guidelines and demands of the project. A complete local assessment covering social, technological and normative aspects is the base to the business model definition. An action plan must then be elaborated with steps to achieve the proposed goals, which can include a pilot project to validate the chosen strategy. As the plan is executed, it should be continuously monitored [19].

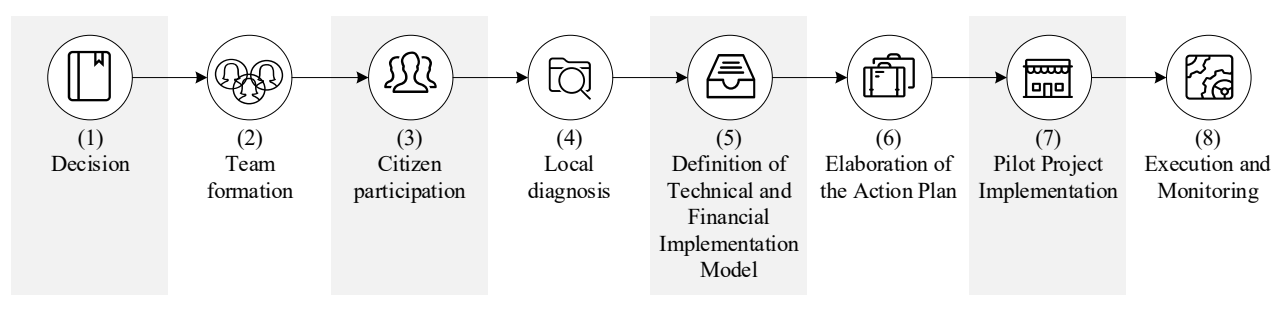

Figure 3: Step by step for the implementation of a smart city.

\section{SOCIAL, TECHNOLOGICAL AND NORMATIVE ASSESSMENT}

Before developing a public policy, it is always essential to make a complete assessment of the current situation. In the case of an IoT implementation strategy in the context of smart cities, the assessment is divided into the study of socio-economic, technological and regulatory factors. Understanding the social conditions of the population, the telecommunications infrastructure and the regulations applied to the project is essential for the making of a successful action plan.

Brasília currently has 3,055,149 inhabitants. The Brazilian capital still attracts many immigrants due to job opportunities, mainly in the public sector, where the majority of the economically active population of the city $(71.8 \%)$ works in the service area, and $15 \%$ are 
civil servants, defense or social security. Brasília's GDP is around $\mathrm{R} \$ 244,682,756,470$ $(€ 37,387,734,220)$, which corresponds to $3.8 \%$ of the national GDP. The median per capita income of Brazil is $\mathrm{R} \$ 30,433.99(€ 4,650)$, however Brasília has the highest per capita income in Brazil, with around R\$80,502.47 (€12,300.84), according to the IBGE [20], [21].

When it comes to the technological context, Brasília has a series of public and private initiatives that can support various initiatives towards a smart city. The Federal District has good connectivity compared to other Brazilian states, where four large private operators offer internet services at the last mile. In addition, Brasília has coverage of three public fiber optic networks: Gigacandanga for universities, GDFnet for the local government, and Infovía Brasília for the federal government. The GigaCandanga network of REDECOMEP-DF is a community of education and research network that integrates research and higher education institutions in Brasilia. On the other hand, in 2017, the local government inaugurated a new data center, which concentrates all the GDF data and systems, such as the Transparency Portal and those for the issuance of electronic tickets for the metro system. The usable physical area is $260 \mathrm{~m}^{2}$ and the storage capacity reaches 2.5 petabytes. In addition, with a focus on innovation in biotechnology and information and communication technology, BioTIC will be the main pole of scientific, technological and innovation development in Brasília. The project will allow the installation of several companies, as well as research institutions and innovation centers [22].

Along with these initiatives, a series of installed ICT infrastructure with growth potential has been implemented in recent years in various fields [23]. The following information was collected by entities of the local government:

- 5,869 telemetry devices are installed. Data transmission technologies: radio frequency, LoRa and Caesb. Pressure and flow sensors in the water network.

- There are 6,400 establishments with telemetry devices in the Federal District. Real-time monitoring in substations with reading of energy measurements.

- Currently, 600 buildings of the local government are served by SUTIC's Internet network (GDFnet), which represents $33 \%$ of the total buildings of public entities.

- Public transportation benefits, such as complimentary travel for the elderly and students already work with facial biometrics, with a total of 860,080 people in the image registry with active cards.

- In the urban video monitoring project in development by the Secretariat of Public Safety, there are 779 cameras installed in different parts of the city. Facial recognition technology is not yet used.

- 14 hospitals and 37 health units are served with $1 \mathrm{~GB} / \mathrm{s}$ fiber optics. Some big data analysis techniques, machine learning and artificial intelligence are being used.

In Brasília in recent years there has been an effort to regulate the issuance of permits for telecommunication infrastructure, with the intention of promoting the development and deployment of this technology. In the context of the implementation of a smart city, it is essential to understand the opportunities and conditions established by the regulatory context and their implications of an IoT Strategy for Brasília. Six different regulations have been identified, which regulate telecommunications facilities in technical terms and urban parameters, as well as aspects associated with IOT and development plans towards a smart city.

\section{AN IOT ACTION PLAN FOR BRASÍLIA SMART CITY}

Aligned with the provisions of the Federal District Plan for the Internet of Things, six fields of action for the action plan have been considered: (1) Science, Technology and Innovation; 
(2) International outreach; (3) Education and professional training; (4) Connectivity and interoperability infrastructure; (5) Regulation, security and privacy; and (6) Economic feasibility. Activities have been defined for each action area, in accordance with initiatives based on the Internet of Things (IoT). The proposed activities are framed in the needs and dispositions obtained from the evaluation of the city of Brasilia, based on its particular contexts. In addition, as a general framework, for each activity, its taxation towards the fulfillment of one or more sustainable development objectives (SDG) has been defined, as shown in Table 2, in order to frame any provision in this international development context. The actions for each item of the action plan are shown in Tables 3-7.

Table 2: Contribution of the action plan to the SDG.

\begin{tabular}{|c|c|c|c|c|c|}
\hline SDG & $\begin{array}{l}\text { Science, } \\
\text { technology } \\
\text { and } \\
\text { innovation }\end{array}$ & $\begin{array}{l}\text { International } \\
\text { outreach }\end{array}$ & $\begin{array}{l}\text { Education } \\
\text { and } \\
\text { professional } \\
\text { training }\end{array}$ & $\begin{array}{l}\text { Connectivity and } \\
\text { interoperability } \\
\text { infrastructure }\end{array}$ & $\begin{array}{l}\text { Regulation, } \\
\text { security and } \\
\text { privacy }\end{array}$ \\
\hline 1. No poverty & & & $\mathrm{x}$ & & \\
\hline $\begin{array}{l}\text { 3. Good } \\
\text { health and } \\
\text { well-being }\end{array}$ & & $\mathrm{x}$ & & & \\
\hline $\begin{array}{l}\text { 4. Quality } \\
\text { education }\end{array}$ & & & $\mathrm{x}$ & & \\
\hline $\begin{array}{l}\text { 5. Gender } \\
\text { equality }\end{array}$ & & & $\mathrm{x}$ & & \\
\hline $\begin{array}{l}\text { 7. Affordable } \\
\text { and clean } \\
\text { energy }\end{array}$ & & $\mathrm{x}$ & & & \\
\hline $\begin{array}{l}8 . \text { Decent } \\
\text { work and } \\
\text { economic } \\
\text { growth } \\
\end{array}$ & & $\mathrm{x}$ & $\mathrm{x}$ & & \\
\hline $\begin{array}{l}\text { 9. Industry, } \\
\text { innovation } \\
\text { and } \\
\text { infrastructure }\end{array}$ & $\mathrm{x}$ & & & $\mathrm{x}$ & $\mathrm{x}$ \\
\hline $\begin{array}{l}\text { 10. Reducing } \\
\text { inequality }\end{array}$ & & & $\mathrm{x}$ & & \\
\hline $\begin{array}{l}11 . \\
\text { Sustainable } \\
\text { cities and } \\
\text { communities } \\
\end{array}$ & $\mathrm{x}$ & $\mathrm{x}$ & $\mathrm{x}$ & $\mathrm{x}$ & $\mathrm{x}$ \\
\hline $\begin{array}{l}12 . \\
\text { Responsible } \\
\text { consumption } \\
\text { and } \\
\text { production }\end{array}$ & $\mathrm{x}$ & & & & \\
\hline $\begin{array}{l}\text { 13. Climate } \\
\text { action }\end{array}$ & & $\mathrm{x}$ & & $\mathrm{x}$ & \\
\hline
\end{tabular}


Table 3: Action plan for science, technology and innovation.

\begin{tabular}{|l|l|}
\hline Item & Description \\
General \\
description & $\begin{array}{l}\text { Program for the integration of local technological initiatives seeks to create } \\
\text { an ecosystem of science, technology and innovation in the city of Brasília. } \\
\text { It includes the following actions: R\&D technical tables; scholarships for } \\
\text { foreign human capital; conferences and local outreach fairs; and start-up } \\
\text { incubation. }\end{array}$ \\
\hline Impact & $\begin{array}{l}\text { The impact on the city is related to the focuses defined within the program } \\
\text { and is related to the following aspects: Consolidation of the SC-IoT } \\
\text { ecosystem; creation of 20 technology-based companies; DF as the focus of } \\
\text { SC-IoT; IoT infrastructure installed and operating in Brasília, for the } \\
\text { benefit of citizens. }\end{array}$ \\
\hline Model & $\begin{array}{l}\text { Public-private partnership financing model, where public spending is } \\
\text { focused on ecosystem development, and private investment on } \\
\text { implementations. }\end{array}$ \\
\hline Monitoring & $\begin{array}{l}\text { Implementation: Phase 1: 1-year, technical tables and ecosystem, and } \\
\text { selection of start-ups; Phase 2: 1-year, consolidates the ecosystem, local } \\
\text { R\&D policies, usable start-up prototypes, pilot tests; and Phase 3: one } \\
\text { year, implementation of the initiatives. } \\
\text { KPIs: No. of experts (minimum five in 2 years); Number of incubated } \\
\text { start-ups (minimum 20 in 2 years); Number of members and typologies in } \\
\text { technical tables; and Number of initiatives in pilot tests. }\end{array}$ \\
\hline
\end{tabular}

Table 4: Strategy for international outreach.

\begin{tabular}{|l|l|}
\hline Item & Description \\
\hline $\begin{array}{l}\text { General } \\
\text { description }\end{array}$ & $\begin{array}{l}\text { The transformation of Brasília into a smart city requires a process that } \\
\text { includes the participation and collaboration of its citizens, seeking a better } \\
\text { quality of life, based on a more human-scale habitat that is sustainable in } \\
\text { the long term. It includes Informative display; and International } \\
\text { Promotion: Science and Technology International Fair. }\end{array}$ \\
\hline Impact & $\begin{array}{l}\text { The culture change that is expected to be achieved will be noted in the } \\
\text { international event, while visitors, whether they are representatives of } \\
\text { companies or enthusiasts, can experience throughout Brasília what it is like } \\
\text { to live in a smart city. This aims to be an example for the entire region and } \\
\text { strengthen the potential to turn the city into an important tourist } \\
\text { destination. }\end{array}$ \\
\hline Model & $\begin{array}{l}\text { Public-private partnership financing model. } \\
\text { Implementation: Stage 1, year 1: Development of government } \\
\text { communication plans, the axes of smart development and its promotion at } \\
\text { the local level and preparation of the necessary event facilities. Stage 2, } \\
\text { year 2: Fair promotion contracts and confirmation of participants. Stage 3, } \\
\text { year 3: Hosting the international event. } \\
\text { KPIs: Indicators of } \mathrm{CO}_{2} \text { emitted and others; Level of local, national and } \\
\text { international knowledge about the Smart Brasília fair in social media and } \\
\text { online visits; \% of advance; number of participants; and number of closed } \\
\text { deals. }\end{array}$ \\
\hline
\end{tabular}


Table 5: Strategy for education and professional training.

\begin{tabular}{|l|l|}
\hline Item & Description \\
\hline $\begin{array}{l}\text { General } \\
\text { description }\end{array}$ & $\begin{array}{l}\text { In the last ten years, many problems in education have been gradually } \\
\text { overcome, due to the economic development of Brazil and in particular } \\
\text { Brasilia, but another factor has emerged that is based on households and its } \\
\text { lack of assistance to minors in terms of guiding adults to help facing the } \\
\text { challenges of the future, which has influenced a discouragement in the } \\
\text { perseverance of the students. }\end{array}$ \\
\hline Impact & $\begin{array}{l}\text { Reduction of social gaps, through the support of new ICTs. Better } \\
\text { coverage and quality of school education, and technical skills. Increase the } \\
\text { opportunities in informal settlements of accessing jobs in ICT companies. } \\
\text { Reinforce the involvement of parents and guardians through ICT School } \\
\text { for Parents. }\end{array}$ \\
\hline Model & $\begin{array}{l}\text { Implementation: Long-term, analyzing the performance of students in } \\
\text { school. For adults, results will depend on how many students are getting a } \\
\text { job. } \\
\text { KPIs: \% of students who resume studies; \% dropout of secondary students } \\
\text { incorporated into the ICT learning model; \% of teachers trained in digital; } \\
\text { Number of older women, who resume their basic studies in technology; \% } \\
\text { growth of online training; employment index by gender and educational } \\
\text { level. }\end{array}$ \\
\hline
\end{tabular}

Table 6: Strategy for the connectivity and interoperability infrastructure.

\begin{tabular}{|l|l|}
\hline Item & Description \\
\hline $\begin{array}{l}\text { General } \\
\text { description }\end{array}$ & $\begin{array}{l}\text { Brasília must review in its computer systems their ability to interact } \\
\text { between the different computer programs and in the data, they generate, } \\
\text { where they are stored, the capacity to standardize formats, process and } \\
\text { cross data between different public administration agencies in local and } \\
\text { federal level and the private sector. }\end{array}$ \\
\hline $\begin{array}{l}\text { By having an interoperability system, the decisions made by the } \\
\text { administration will be more holistic and robust, this will allow it to address } \\
\text { challenges more efficiently, improve public services to citizens, savings in } \\
\text { the municipality's budget and planning that can reinforce programs } \\
\text { socially. On the other hand, if the databases are open by default, it will } \\
\text { allow the development of a source of entrepreneurial projects that have } \\
\text { citizens as clients. }\end{array}$ \\
\hline Model & $\begin{array}{l}\text { Implementation: Design stage lasts 1 year: Hiring companies for system } \\
\text { and workforce assessment; Bidding Stage 1 year: Raising of Public- } \\
\text { Private proposals, tender, adjudication, and allocation of resources; } \\
\text { Implementation stage lasts 2 years. } \\
\text { KPIs: Level of interoperability of computer systems at the community } \\
\text { level; Online digital certificate numbers; Savings in expenses for process } \\
\text { digitization; Income from new industrial and commercial patents in the } \\
\text { city. }\end{array}$ \\
\hline
\end{tabular}


Table 7: Strategy for regulation, security and privacy.

\begin{tabular}{|l|l|}
\hline Item & Description \\
General & $\begin{array}{l}\text { Brasília must ensure the security and privacy of its citizens' data, which } \\
\text { are incorporated into the databases of public bodies through the } \\
\text { digitization of processes on a voluntary basis, or by capturing them, due to } \\
\text { IoT sensors, which are necessary for a better management and } \\
\text { administration of the city. }\end{array}$ \\
\hline Impact & $\begin{array}{l}\text { The confidence of citizens in the Governance management systems must } \\
\text { be complete, this implies that the information they develop in the data } \\
\text { analysis is duly protected, allowing to strengthen the support for the } \\
\text { management of the authorities, in technological investments each time } \\
\text { more sophisticated, which help improve the well-being of citizens and the } \\
\text { environment. }\end{array}$ \\
\hline Model & $\begin{array}{l}\text { Public funding } \\
\text { Implementation: Stage 1 is the uniformization, in public bodies, of the } \\
\text { request procedure for collection and use of personal data; Stage 2 is the } \\
\text { dissemination of the personal data protection law and informative talks to } \\
\text { all public officials, school civic education classes and dissemination } \\
\text { through open TV channels. } \\
\text { KPIs: Number of media that participated in the disclosure of the personal } \\
\text { data protection law and \% of population coverage; Percentage of public } \\
\text { officials attending talks on the data protection law. }\end{array}$ \\
\hline
\end{tabular}

The aspect of economic feasibility was done by analyzing the financial capacity to undertake the above mentioned strategies. Brasília has an approximate annual budget of $€ 6,482,000,000$. The proposed action plan considers an implementation cost of $€ 50,000,000$. The implementation of the action plan is mainly based on a cost of approximately $0.53 \%$ of the city annual budget. The plan allows to visualize and support the development of a humancentered smart city.

\section{CONCLUSIONS}

The social and technological preparation for the implementation of IoT devices in Brasília that this paper proposes depends on political coordination and budgetary forecasting. The city has a unique condition in Brazil, due to its high social development, which can serve as an example to the entire country and also Latin America. However, the city must overcome the management challenges, coordinating the actions of the different entities of the administration for the common objective of implementing a complete and efficient IoT strategy. The preparation for the IoT will be very beneficial because it will also prepare the city for the advent of $5 \mathrm{G}$ and all its potentialities. The implantation of antennas must be coordinated and accompanied by the modernization of the applicable regulations. Although the costs are significant, the socio-economic development and the financial return provided by the massive deployment of IoT can inaugurate a new phase of economic development in Brasília. It must be ensured that Brasília is not just another city that can buy technology, but one that can lead the development and deployment of the IoT on a massive scale at the municipal level. The training of youth and workers, and the attraction and retention of talents in the city is essential in order to fulfill this goal. 


\section{ACKNOWLEDGEMENTS}

This work has been supported by the CONICYT for its economic support to Felipe Muñoz, beneficiary of a pre-doctoral grant (CONICYT - PCHA/International Doctorate/201972200306) and by TERRACAP for its economic support to the Master Smart City Manager course at Zigurat Institute of Technology of Bruno Ávila Eça de Matos. The following entities of the Federal District Government provided information to the researchers: SECTI/DF, CAESB, CEB, SUTIC, SEMOB/DF, SSP/DF, SES/DF.

\section{REFERENCES}

[1] Ullah, F., Qayyum, S., Thaheem, M.J., Al-Turjman, F. \& Sepasgozar, S.M.E., Risk management in sustainable smart cities governance: A TOE framework. Technol. Forecast. Soc. Change, 167(March), 120743, 2021.

DOI: 10.1016/j.techfore.2021.120743.

[2] Ahad, M.A., Paiva, S., Tripathi, G. \& N. Feroz, N., Enabling technologies and sustainable smart cities. Sustain. Cities Soc., 61(June), 102301, 2020.

DOI: $10.1016 /$ j.scs.2020.102301.

[3] Burns, R., Fast, V., Levenda, A. \& Miller, B., Smart cities: Between worlding and provincialising. Urban Stud., 58(3), pp. 461-470, 2021.

DOI: $10.1177 / 0042098020975982$.

[4] Sharma, M., Joshi, S., Kannan, D., Govindan, K., Singh, R. \& Purohit, H.C., Internet of Things (IoT) adoption barriers of smart cities' waste management: An Indian context. J. Clean. Prod., 270, 122047, 2020. DOI: 10.1016/j.jclepro.2020.122047.

[5] Syed, A.S., Sierra-Sosa, D., Kumar, A. \& Elmaghraby, A., IoT in Smart Cities: A survey of technologies, practices and challenges. Smart Cities, 4(2), pp. 429-475, 2021. DOI: $10.3390 /$ smartcities4020024.

[6] Governo do Distrito Federal, About Brasília, 2021. http://www.brasilia.df.gov.br/ category/sobre-brasilia/. Accessed on: 21 May 2021.

[7] Araujo, V., Mitra, K., Saguna, S. \& Åhlund, C., Performance evaluation of FIWARE: A cloud-based IoT platform for smart cities. J. Parallel Distrib. Comput., 132, pp. 250-261, 2019. DOI: 10.1016/j.jpdc.2018.12.010.

[8] Hammi, B., Khatoun, R., Zeadally, S., Fayad, A. \& Khoukhi, L., IoT technologies for smart cities. IET Networks, 7(1), pp. 1-13, 2018. DOI: 10.1049/iet-net.2017.0163.

[9] Bregni, S., Décina, M., Giacomazzi, P. \& Poli, A., Milano digital city: Planning the municipal wireless network of Milano. 2009 IEEE Latin-American Conf. Commun. LATINCOM '09 - Conf. Proc., 2009. DOI: 10.1109/LATINCOM.2009.5305139.

[10] Hayat, P., Smart cities: A global perspective. India Q., 72(2), pp. 177-191, 2016. DOI: $10.1177 / 0974928416637930$.

[11] NYC Mayor's Office of the Chief Technology Officer, NYC, Guidelines for the Internet of Things, 2021. https://iot.cityofnewyork.us/. Accessed on: 20 May 2021.

[12] Hwang, J.-S. \& Choe, Y.H., Smart Cities Seoul: A Case Study, 2013.

[13] Ajuntament de Barcelona, Sentilo BCN, 2021. http://connecta.bcn.cat/connectacatalog-web/component/map. Accessed on: 20 May 2021.

[14] Anand, S., IoT-enabled smart city framework for Jaipur, 2021. https://www.stl.tech/ brain-share/white-papers/iot-enabled-smart-city-framework-for-jaipur.html. Accessed on: 21 May 2021.

[15] Innovate Vegas, Six pillars of smart Vegas, 2021. https://innovate.vegas/Old-Pages/ Programs-Projects/smart-city. Accessed on: 21 May 2021).

[16] RIO Prefeitura, City Hall signs PPP of public lighting, 2020. https://prefeitura.rio/ cidade/crivella-assina-ppp-da-iluminacao-publica/. Accessed on: 21 May 2021. 
[17] Sadowski, J. \& Maalsen, S., Modes of making smart cities: Or, practices of variegated smart urbanism. Telemat. Informatics, 55, 101449, 2020. DOI: $10.1016 /$ j.tele.2020.101449.

[18] Guo, Y.M., Huang, Z.L., Guo, J., Li, H., Guo, X.R. \& Nkeli, M.J., Bibliometric analysis on smart cities research. Sustain., 11(13), 2019. DOI: 10.3390/su11133606.

[19] Barkis, W. et al., The Municipal Internet of Things (IoT) Blueprint, 2019. https://pages.nist.gov/GCTC/super-clusters/.

[20] IBGE, Brasília, 2021. https://cidades.ibge.gov.br/brasil/df/brasilia/panorama. Accessed on: 21 May 2021.

[21] CODEPLAN, PDAD 2018 - Destaques, Pesquisa Nacional por Amostra de Domicílios (PDAD). pp. 2013-2016, 2018.

[22] Ortega, J., Brasília Technology Park and Huawei conduct first 5G test in the country, 2019. https://www.startse.com/noticia/nova-economia/parque-tecnologico-de-brasilia -e-huawei-realizam-primeiro-teste-de-5g-no-pais. Accessed on: 20 May 2021.

[23] Sistema integrado de normas juridicas do DF, DECRETO No 40.625, 2020. 